Józefa Matejek

Uniwersytet Pedagogiczny

im. Komisji Edukacji Narodowej

w Krakowie
Kiedy myślimy Rodzina..., red. M. Duda,

K. Kutek-Sładek, Kraków 2016, s. 349-359

(Praca Socjalna w Teorii i Działaniu, 2).

DOI: http://dx.doi.org/10.15633/9788374385091.25

\title{
Wychowanie w rodzinnej opiece zastępczej szansą dla dzieci osieroconych społecznie
}

Education in family foster care is a chance for children orphaned socially

Abstract: In situations of occuring in
the family serious difficulties regard-
ing the discharge of the primary func-
tions, the need arises to secure paren-
tal care and upbringing of children. In
this aspect, forms of foster care are the
best ways to support the family. Foster families are therefore crucial in supporting the child and family's environment in dysfunction emerging situations and social orphanhood

Keywords: foster families, family support, social orphanhood

Rodzina jako naturalne i podstawowe środowisko narodzin i rozwoju człowieka wywiera znaczący wpływ na jego zachowanie oraz stosunek do świata wartości, norm i wzorów postępowania. Dokonujące się w społeczeństwie różnorodne zmiany o charakterze społeczno-ekonomicznym, gospodarczym oraz kulturowym obok wielu pozytywnych skutków przynoszą również niekorzystne zjawiska i problemy społeczne, które w konsekwencji mogą oddziaływać na funkcjonowanie rodziny. Przemiany, jakim podlega rodzina, mogą prowadzić do zachwiania jej stabilności w sferze warunków materialno-ekonomicznych i bytowych, a także niejednokrotnie przyczyniają się do występowania kryzysów rodzinnych, których przyczyny można sprowadzić do następujących źródeł:

- tkwiące w samych rodzicach (np. alkoholizm, niezaradność życiowa, nieprawidłowa komunikacja), 
- związane z dziećmi (np. dziecko nadpobudliwe, nerwowe, sprawiające trudności wychowawcze czy dziecko niepełnosprawne),

- negatywne sytuacje wychowawcze (np. nieobecność rodziców w procesie wychowywania dziecka, przesadny rygoryzm lub zbytni liberalizm, niewłaściwe postawy wychowawcze $)^{1}$.

Pojawienie się w rodzinie trudności w zakresie wywiązywania się z podstawowych funkcji rodzicielskich oraz towarzyszące im napięcia emocjonalne nie stwarzają klimatu odpowiedniego dla właściwego rozwoju dzieci, kształtowania pozytywnych wartości, wzorów i norm postępowania. Niejednokrotnie w takiej sytuacji konieczne staje się umieszczenie dziecka poza rodziną naturalną. Najwłaściwszą formą opieki zastępczej jest w takiej sytuacji opieka typu rodzinnego, ponieważ jak zauważa Andrzej Łuczyński, „zapewnia to dziecku ciągłość opieki i wychowania w warunkach rodzinnych, a rodzicom biologicznym dziecka daje szansę na uzdrowienie sytuacji rodzinnej i powrót dziecka do rodziny własnej" ${ }^{2}$. W sytuacji pojawiających się w rodzinie poważnych problemów rodzina może uzyskać pomoc zgodnie z zapisem ustawy o wspieraniu rodziny i systemie pieczy zastępczej ${ }^{3}$, w której czytamy, iż „wspieranie rodziny przeżywającej trudności w wypełnianiu funkcji opiekuńczo-wychowawczych to zespół planowych działań mających na celu przywrócenie rodzinie zdolności do wypełniania tych funkcji [...]. Obowiązek wspierania rodziny przeżywającej trudności w wypełnianiu funkcji opiekuńczo-wychowawczych oraz organizacji pieczy zastępczej, w zakresie ustalonym ustawą, spoczywa na jednostkach samorządu terytorialnego oraz na organach administracji rządowej"4. Wspieranie rodziny w takiej sytuacji jest prowadzone $\mathrm{w}$ formie pracy $\mathrm{z}$ rodziną oraz pomocy $\mathrm{w}$ opiece $\mathrm{i}$ wychowaniu dziecka ${ }^{5}$ przez instytucje i podmioty działające na rzecz dziecka i rodziny, placówki wsparcia dziennego oraz rodziny wspierające ${ }^{6}$. Należy podkreślić, iż wprowadzenie w życie ustawy o wspieraniu rodziny i systemie pieczy zastępczej umocniło istniejące i wprowadziło nowe rozwiązania systemowe w pracy z rodziną, która doświadcza trudności - zarówno rodziną naturalną, jak i zastępczą.

L. Winogrodzka, Rodziny zastępcze i ich dzieci, Lublin 2007, s. 53-54.

A. Łuczyński, Dzieci w rodzinach zastępczych i dysfunkcjonalnych, Lublin 2008, s. 105.

3 Ustawa z dnia 9 czerwca 2011 roku o wspieraniu rodziny i systemie pieczy zastępczej, Dz. U. z 2015 poz. 332.

4 Tamże, art. 2 pkt 1 oraz art. 3 pkt 1.

5 Tamże, art. 8 pkt 2.

6 Tamże, art. 9. 


\section{Sieroctwo społeczne dziecka}

Współczesna rodzina napotyka różnorodne utrudnienia, które mogą stać się zagrożeniem dla jej prawidłowego funkcjonowania w społeczeństwie, co w konsekwencji stanowi przyczynę jej dysfunkcji oraz destabilizacji: ,,traktując rodzinę jako całość, jako ów integralny i niezależny byt, trzeba przyjąć, iż jakiekolwiek zaburzenie, utrudniające rodzinie realizację którejś z podstawowych funkcji, może powodować przejściową lub dłuższą niewydolność ogólnego jej funkcjonowania, czyli dysfunkcyjność"7. Wszelkie zmiany, które dokonują się w rodzinie, mają wpływ na funkcjonowanie poszczególnych jej członków, a najmocniej dotykają one dzieci, które mogą doświadczać sieroctwa społecznego. Sieroctwo jest zjawiskiem wieloaspektowym i złożonym ${ }^{8}$, dlatego wiele uwagi poświęca się podejmowaniu różnorodnych zadań dotyczących jego kompensacji. Pojęcie sieroctwa podlegało przemianom, ponieważ początkowo termin „sierota” określał dzieci pozbawione opieki na skutek śmierci rodziców, natomiast sytuację, w której rodzice nie sprawowali opieki nad dzieckiem - porzucali je, nazywano opuszczeniem. Sieroctwo społeczne to stan, w którym dziecko zostaje ,,pozbawione odpowiedniej opieki rodzicielskiej, podobnie jak to się dzieje w przypadku sieroctwa naturalnego, choć oboje rodzice (lub przynajmniej jedno z nich) żyją" ". Stanisław Kozak sieroctwo społeczne określa jako „zjawisko braku opieki rodzicielskiej wynikające głównie z zaburzeń w funkcjonowaniu rodziny: braku troski o dziecko, przestępczości i demoralizacji rodziców, alkoholizmu i poważnych błędów wychowawczych"10. Z sieroctwem społecznym mamy zatem do czynienia w sytuacji występowania rażącego zaniedbania opiekuńczo-wychowawczego wobec dzieci. Ponadto charakterystyczną cechą sieroctwa społecznego zdaniem Ireny Obuchowskiej jest „sytuacja zagubienia, którą powoduje przede wszystkim instytucjonalizacja opieki nad dzieckiem. Składa się na nią niestabilność uczuciowa, niejednoznaczna przynależność dziecka oraz niejednolitość sta-

7 T. Sakowicz, Dysfunkcjonalność rodziny a resocjalizacja, Kraków 2006, s. 43.

8 Zob. A. Szymborska, Sieroctwo społeczne, Warszawa 1969; S. Kozak, Sieroctwo społeczne, Warszawa 1986; I. Obuchowska, Dziecko zagubione w sieroctwie, „Problemy Opiekuńczo-Wychowawcze" (1998) nr 5, s. 3-8; B. Czeredrecka, Potrzeby psychiczne sierot społecznych, Warszawa 1988; M. Łopatkowa, Samotność dziecka, Warszawa 1989; I. Wagner, Sieroctwo społeczne - przyczyny, następstwa, formy kompensacji: studium teoretyczno-badawcze, Częstochowa 1997; M. Sendyk, Społeczne przystosowanie dzieci z poczuciem sieroctwa duchowego, Kraków 2001; Z. Węgierski, Opieka nad dzieckiem osieroconym: teoria i praktyka, Toruń 2006; T. E. Olearczyk, Sieroctwo i osamotnienie. Pedagogiczne problemy kryzysu współczesnej rodziny, Kraków 2008.

9 A. Szymborska, Sieroctwo społeczne, Warszawa 1969, s. 13.

10 S. Kozak, Sieroctwo społeczne, Warszawa 1986, s. 5. 
wianych dziecku wzorów postępowania, które to przyczyniają się do zaburzeń rozwoju osobowości"11.

Analizując przyczyny występowania zjawiska sieroctwa społecznego, dostrzegamy wiele czynników, które bezpośrednio związane są z taką sytuacją: uzależnienia, a zwłaszcza alkoholizm, złe warunki materialne, występującą w rodzinie demoralizację, chorobę rodziców, rozpad rodziny (rozwód), porzucenie dziecka czy odebranie władzy rodzicielskiej. Janina Maciaszkowa przyczyn sieroctwa doszukuje się również w uwarunkowaniach życia społecznego ${ }^{12}$, natomiast Róża Pawłowska i Elżbieta Jundziłł wyróżniają dwie grupy przyczyn sieroctwa społecznego: makrospołeczne i mikrospołeczne ${ }^{13}$. Do przyczyn makrospołecznych zaliczyć można ogólną sytuację społeczno-polityczną i towarzyszące jej zjawiska, takie jak np. bezrobocie i bezdomność, natomiast przyczyny mikrospołeczne dotyczą niewłaściwego funkcjonowania rodziny w sferze wychowawczej, występowania zjawisk patologicznych w rodzinie oraz zaburzonej struktury rodziny. Źródeł zjawiska sieroctwa społecznego należy szukać także w niezaspokajaniu podstawowych potrzeb dziecka, zaniedbywaniu oraz braku akceptacji ze strony rodziców biologicznych.

Biorąc pod uwagę wymienione czynniki, występujące w rodzinie, oraz towarzyszące im konsekwencje będące skutkiem braku zapewnienia odpowiednich warunków opiekuńczo-wychowawczych przez rodzinę, a także pomimo wszelkich działań o charakterze profilaktycznym i wspierającym kierowanych do rodziny biologicznej, jeżeli nie przynoszą one oczekiwanych pozytywnych rezultatów, istnieje konieczność zabrania dziecka z rodziny i zgodnie z postanowieniem sądu umieszczenia $\mathrm{w}$ jednej z dwóch form pieczy zastępczej: rodzinnej lub instytucjonalnej.

\section{Wychowanie dziecka w rodzinie zastępczej}

Rodzina zastępcza to najogólniej mówiąc każde środowisko wychowawcze utworzone przez osoby niebędące rodzicami naturalnymi dziecka, które powstaje w celu zapewnienia dziecku pozbawionemu całkowicie lub częściowo opieki rodzicielskiej zastępczego środowiska wychowawczego. Rodzina zastępcza jest formą opieki tymczasowej do momentu unormowania się sytuacji życiowej dziecka. Marek Andrzejewski wyjaśnia, iż „piecza zastępcza to piecza nad

11 Zob. M. Joachimowska, Rodzicielstwo zastępcze. Idea - problemy - analizy - kompetencje, Bydgoszcz 2008, s. 49.

12 J. Maciaszkowa, Z teorii i praktyki pedagogiki opiekuńczej, Warszawa 1991, s. 9-92.

13 R. Pawłowska, I. Jundziłł, Pedagogika człowieka samotnego, Gdańsk 2000, s. 216. 
dzieckiem przebywającym poza swym środowiskiem rodzinnym lub które ze względu na własne dobro nie może przebywać w tym środowisku. Piecza zastępcza jest roztaczana przez inne osoby niż rodzice lub przez specjalnie powołane do tego instytucje"14. Mirosław Jamrożek i Bożena Matyjas określają rodzinę zastępczą jako małą grupę społeczną, przy czym rodzina ta stanowi środowisko wychowawcze utworzone przez osoby niebędące naturalnymi rodzicami dziec$\mathrm{ka}^{15}$. Zatem rodzina zastępcza jest formą opieki całkowitej okresowej, która powstaje wtedy, gdy małżeństwo lub osoba niepozostająca w związku małżeńskim bierze pod opiekę i na wychowanie nie więcej niż troje dzieci (chyba że chodzi o rodzeństwo), przy czym między tymi osobami nie powstają takie skutki prawne jak przy adopcji. Zgodnie z zapisem zamieszczonym w ustawie o wspieraniu rodziny i systemie pieczy zastępczej „formami rodzinnej pieczy zastępczej są:

- rodzina zastępcza: a) spokrewniona, b) niezawodowa, c) zawodowa, w tym zawodowa pełniąca funkcje pogotowia rodzinnego i zawodowa specjalistyczna,

- rodzinny dom dziecka"16.

Rodzinę zastępczą spokrewnioną tworzą tylko wstępni lub rodzeństwo dziecka, natomiast w przypadku dalszego pokrewieństwa osoby sprawujące pieczę nad dzieckiem są traktowane jako rodzina niezawodowa. Rodzinę zastępczą zawodową mogą stanowić małżonkowie lub osoby samotne, niebędący wstępnymi lub rodzeństwem dziecka. Rodzina zastępcza pełniąca funkcje pogotowia rodzinnego jest formą opieki, w której umieszcza się nie więcej niż troje dzieci na pobyt okresowy do czasu unormowania sytuacji życiowej dziecka (nie dłużej jednak niż na 4 miesiące, niemniej jednak w sytuacjach szczególnie uzasadnionych pobyt dziecka może być przedłużony do 8 miesięcy lub do zakończenia postępowania sądowego dotyczącego ustalenia sytuacji dziecka w zakresie: powrotu do rodziny biologicznej, przysposobienia, umieszczenia w rodzinnej pieczy zastępczej). Do rodziny zastępczej zawodowej specjalistycznej kieruje się „dzieci legitymujące się orzeczeniem o niepełnosprawności lub orzeczeniem o znacznym lub umiarkowanym stopniu niepełnosprawności, dzieci na podstawie ustawy z dnia 26 października 1982 roku o postępowaniu w sprawach nieletnich, małoletnie matki z dziećmi" ${ }^{17}$. W rodzinnym domu dziecka może przebywać łącznie nie więcej niż 8 dzieci lub osób, które osiągnęły pełnoletniość $\mathrm{w}$ trakcie przebywania w opiece zastępczej. W razie konieczności umieszczenia

14 M. Andrzejewski i in., Rodziny zastępcze - problematyka prawna, Toruń 2006, s. 19.

15 M. Jamrożek, B. Matyjas, Rodzina zastępcza, [w:] Encyklopedia pedagogiczna XXI wieku, t. 5, red. E. Różycka, Warszawa 2006, s. 386-389.

16 Ustawa z dnia 9 czerwca 2011 r. o wspieraniu..., dz. cyt., art. 39 pkt. 1.

17 Tamże, art. 59 pkt 1. 
rodzeństwa, za zgodą prowadzącego dom oraz po uzyskaniu pozytywnej opinii koordynatora, dopuszcza się umieszczenie w tym samym czasie większej liczby dzieci. Rodziny zastępcze zawodowe oraz osoby prowadzące rodzinny dom dziecka są zobowiązane do odbycia specjalistycznego szkolenia organizowanego przez organizatora rodzinnej pieczy zastępczej ${ }^{18} \mathrm{i}$ otrzymują za swoją pracę wynagrodzenie. Przy wypełnianiu swojej funkcji rodzina zastępcza oraz prowadzący rodzinny dom dziecka współpracują z organizatorem rodzinnej pieczy zastępczej, koordynatorem rodzinnej pieczy zastępczej, ośrodkiem adopcyjnym oraz instytucjami i osobami, których obecność jest istotna w procesie wychowania dziecka. Należy podkreślić, iż wychowawczo-opiekuńczy aspekt funkcjonowania rodziny zastępczej wielokrotnie był podejmowany przez badaczy tego środowiska, między innymi przez: Aleksandra Tynelskiego ${ }^{19}$; Elżbietę Różańską, Aleksandra Tynelskiego ${ }^{20}$; Czesława Kępskiego ${ }^{21}$; Różę Pawłowskąą; Urszulę Kusio ${ }^{23}$; Lidię Winogrodzką ${ }^{24}$; Andrzeja Łuczyńskiego ${ }^{25}$; Magdalenę Joachimowską ${ }^{26}$; Józefę Matejek, Marka Banacha ${ }^{27}$; Marzenę Ruszkowską ${ }^{28}$.

Zadania, jakie spełnia rodzina zastępcza, obejmują zakres codziennych czynności opiekuńczo-wychowawczych: „bieżąca piecza to faktyczna, codzienna troska o stan zdrowia dziecka, jego naukę, wypoczynek, sposób spędzania wolnego czasu, zapewnienie dziecku poczucia bezpieczeństwa, stabilizacji i pozostawanie z nim we wspólnocie rodzinnej”29. Zakres obowiązków, jakie w tym względzie ma do spełnienia rodzina zastępcza, dotyczy także wyrównywania braków rozwojowych i szkolnych dziecka, zaspokajania potrzeb emocjonalnych, byto-

18 Zob. Ustawa z dnia 9 czerwca 2011 r. o wspieraniu..., dz. cyt., art. 44.

19 A. Tynelski, Rodzina zastępcza jako środowisko opiekuńczo-wychowawcze, „Problemy Opiekuńczo-Wychowawcze" (1976) nr 3.

20 E. Różańska, A. Tynelski, Rodzina zastępcza jako forma opieki nad dzieckiem, Kielce 1981.

21 Cz. Kępski, Rodziny zastępcze w województwie lubelskim, „Problemy Opiekuńczo-Wychowawcze" (1985) nr 2.

22 R. Pawłowska, Rola rodziny zastępczej w readaptacji dziecka osieroconego, „Problemy Opiekuńczo-Wychowawcze" (1987) nr 9.

23 U. Kusio, Rodzina zastępcza jako środowisko wychowawcze. Studium socjologiczne na przykładzie Lublina, Lublin 1998.

24 L. Winogrodzka, Rodziny zastępcze i ich dzieci, Lublin 2007.

25 A. Łuczyński, Dzieci w rodzinach zastępczych..., dz. cyt..

26 M. Joachimowska, Rodzicielstwo zastępcze..., dz. cyt.

27 J. Matejek, M. Banach, Realizacja funkcji opiekuńczo-wychowawczych w rodzinach zastępczych, [w:] Dilema sociálnej pedagogiky: výchova alebo prostredie?, Vedecký zborník, edit. M. Pisoňová, D. Smetanová, M. Kuruc, Bratislava 2013.

28 M. Ruszkowska, Diagnoza rodzin zastępczych $w$ obliczu dylematów współczesności, Warszawa 2013.

29 D. Wosik-Kawala, Rodzinne i instytucjonalne środowiska opiekuńczo-wychowawcze, Lublin 2012, s. 107. 
wych, społecznych, zdrowotnych, a także rozwój zainteresowań i uzdolnieńn ${ }^{30}$. Przejście dziecka do środowiska rodziny zastępczej jest sytuacją trudną zarówno dla niego, jak i dla rodziny, a ponadto dzieci kierowane do rodzin zastępczych niejednokrotnie są zaniedbane pod względem wychowawczym, co przekłada się również na występujące opóźnienia w rozwoju fizycznym i psychicznym. Brak odpowiedniej troski o charakterze wychowawczym może prowadzić do zaburzeń w rozwoju dziecka w zakresie tworzenia więzi z członkami rodziny oraz komunikacji z otoczeniem. Jest to bardzo istotna kwestia, jeśli się weźmie pod uwagę, iż według danych GUS w 2013 roku w naszym kraju funkcjonowało 38,9 tys. rodzin zastępczych oraz 331 rodzinnych domów dziecka, zapewniając opiekę i wychowanie dla 57442 dzieci, wśród których największy odsetekstanowiły dzieci w wieku 7-13 lat (21,8 tys., tj. 37,9 proc.,) oraz 14-17 lat (17,7 tys., tj. 30,8 proc.). Mniej było dzieci najmłodszych: w przedziale wiekowym 0-3 lata 4,8 tys., co stanowiło 8,3 proc. ogółu dzieci, natomiast wychowanków w wieku 4-6 lat było 5,9 tys., tj. 10,2 proc.; w tej grupie znalazły się także osoby w wieku 18-24 lata, których było 7,3 tys., tj. 12,8 proc. ${ }^{31}$.

Wspieranie wszechstronnego rozwoju dziecka w rodzinie zastępczej zgodnie z jego potencjałem oraz indywidualnymi możliwościami na różnych etapach rozwoju stanowi podstawowe zadanie w obszarze wychowania, jakie spoczywa na opiekunach zastępczych. Istotnego znaczenia nabiera tutaj również motywacja dziecka do podejmowania zadań w zakresie kształcenia i nabywania różnorodnych umiejętności zarówno w aspekcie organizacji życia rodzinnego, jak i relacji społecznych. W rodzinie kształtuje się znajomość zasad i reguł właściwego funkcjonowania, norm moralnych oraz odpowiedzialności i konsekwencji w zakresie podejmowanych decyzji. Rodzina zastępcza w myśl obowiązujących przepisów ma obowiązek podtrzymywać kontakty z rodzicami biologicznymi dziecka ${ }^{32}$, co stanowi także ważny element wychowania, ponieważ uczy otwartości, budowania właściwych relacji i więzi, zapewniając ciągłość rodziny i umacniając dziecko w poczuciu przynależności do niej.

$\mathrm{W}$ procesie wychowania dziecka $\mathrm{w}$ rodzinie zastępczej istotne znaczenie ma również okres jego pobytu w nowym środowisku. Czas trwania pieczy nad dzieckiem wyznaczony jest przede wszystkim przez charakter przyczyn, które doprowadziły do umieszczenia dziecka poza rodziną własną, ma również związek z możliwościami pracy z dzieckiem oraz przyjętymi działaniami wychowawczymi, między innymi w zakresie nauki systematyczności podejmowanych działań,

30 Zob. Ustawa z dnia 9 czerwca 2011 r. o wspieraniu ..., dz. cyt, art. 40 pkt 1.

31 Główny Urząd Statystyczny, Opieka nad dzieckiem pozbawionym opieki rodzicielskiej (Notatka informacyjna), Warszawa 2014, s. 2-3.

32 Ustawa z dnia 9 czerwca 2011 r. o wspieraniu..., dz. cyt., art. 33 pkt 2. 
cierpliwości, konsekwencji w zaplanowanych zadaniach itp. Piecza zastępcza na mocy prawa jest sprawowana do ukończenia przez wychowanka 18. roku życia ${ }^{33}$. Osoba, która osiągnęła pełnoletność przebywając w pieczy zastępczej, może pozostać w dotychczasowej rodzinie zastępczej lub rodzinnym domu dziecka, nie dłużej jednak niż do ukończenia 25. roku życia, jeżeli: „1) uczy się: a) w szkole, b) w zakładzie kształcenia nauczycieli, c) w uczelni, d) u pracodawcy w celu przygotowania zawodowego lub 2) legitymuje się orzeczeniem o znacznym lub umiarkowanym stopniu niepełnosprawności i uczy się: a) w szkole, b) w zakładzie kształcenia nauczycieli, c) w uczelni, d) na kursach, jeśli ich ukończenie jest zgodne $\mathrm{z}$ indywidualnym programem usamodzielnienia, e) u pracodawcy w celu przygotowania zawodowego" 34 .

Proces wychowania w rodzinie zastępczej jest złożonym i długotrwałym okresem wspólnej pracy z dzieckiem, wymagającym wiele uwagi, zaangażowania i zrozumienia, ale tylko dzięki właściwej stymulacji rozwoju możliwa jest kompensacja wcześniejszych braków, rozumiana jako „złożony proces uzupełniania, wyrównywania braków oraz zastępowania (substytucji) deficytów rozwojowych"35, oraz prawidłowy bieżący rozwój dziecka. Rodzina w aspekcie pedagogicznym jest środowiskiem wychowania dzieci i jak podkreśla Irena Jundziłł, „,rodzina tworzy naturalne środowisko wychowawcze, w którym główne elementy stanowią interakcje zachodzące między poszczególnymi jej członkami”36. Dlatego w rodzinie zastępczej kwestia wychowania dziecka nabiera szczególnego znaczenia ze względu na wcześniejsze przeżycia, czasami trudne doświadczenia i doznane krzywdy. Rodziny zastępcze „muszą mieć świadomość, że nie wystarcza tylko stworzenie dziecku odpowiednich warunków wychowawczych; nowa rodzina musi przede wszystkim «rehabilitować» je emocjonalnie. Dziecko musi czuć się pewnie i bezpiecznie, musi nabierać przekonania o rosnącej akceptacji nowej rodziny względem jego osoby" ${ }^{37}$.

Rodzina postrzegana jest jako instytucja wychowania naturalnego, w której zasadniczymi mechanizmami procesu wychowawczego są: mechanizm naśladownictwa i identyfikacji, który związany jest z dawaniem przykładów i wzorów ze strony rodziców - szczególnie w przypadku dzieci młodszych; mechanizm kontroli społecznej, polegający na zastosowaniu wobec dziecka systemu nagród i kar, oraz mechanizm inspirujący i pobudzający odpowiednio ukierun-

\footnotetext{
33 Tamże, art. 37 pkt 1.

${ }_{34}$ Tamże, art. 37 pkt 2.

35 D. Lalak, T. Pilch., Elementarne pojęcia pedagogiki społecznej i pracy socjalnej, Warszawa 1999, s. 114.

36 I. Jundziłł, Opieka nad rodzina w miejscu zamieszkania, Warszawa 1983, s. 16.

37 J. Matejek, Działalność ośrodków adopcyjno-opiekuńczych w procesie przygotowania i wspierania rodzin zastępczych, Kraków 2008, s. 89.
} 
kowaną aktywność dziecka ${ }^{38}$. W środowisku rodzinnej opieki zastępczej dzieci poprzez obserwację, naśladownictwo i uczestnictwo w codziennych relacjach rodzinnych uczą się właściwych postaw społecznych, wypełniania obowiązków oraz odpowiedzialności za swoje postępowanie, a także kształtują relacje z pozostałymi członkami rodziny. W rodzinie zastępczej w aspekcie wychowawczym szczególnego znaczenia nabiera także zaspokojenie potrzeb przyjętych do rodziny dzieci: ,zaspokajanie podstawowych potrzeb dziecka ma zasadnicze znaczenie dla jego pełnego, harmonijnego rozwoju. Niezaspokojenie potrzeb, zwłaszcza podstawowych, wpływa ujemnie na rozwój psychofizyczny dziecka, powoduje opóźnienia rozwojowe i zaburzenia w przystosowaniu" ${ }^{39}$. Ponadto znajomość potrzeb dziecka oraz właściwe ich zaspokojenie wpływa w procesie wychowania na tworzenie odpowiedniej atmosfery życia rodzinnego: „wychowanie służy ukierunkowaniu rozwoju oraz sposobów zaspokajania potrzeb dziecka. Rodzaj i zakres oddziaływania wychowawczego zależy od właściwości potrzeb oraz wieku i doświadczeń społecznych dziecka" ${ }^{40}$. Nie ulega wątpliwości, że właściwie funkcjonująca rodzina odgrywa kluczową rolę w wychowaniu dziecka, dlatego także rodzice zastępczy mają obowiązek zadbać o prawidłowe wychowanie powierzonego im dziecka, podejmując w tym celu wszelkie działania związane z jego rozwojem fizycznym, psychicznym oraz społecznym.

\section{Podsumowanie}

Wychowanie w systemie rodzinnej opieki zastępczej dla dzieci osieroconych społecznie jest bez wątpienia szansą na spokojny, ciepły dom, poznanie właściwych wzorów funkcjonowania rodziny oraz zaspokojenie tych potrzeb, których realizacja była ograniczona lub zupełnie zaniedbana. Rodzice zastępczy mogą odegrać niezwykle pozytywną rolę w procesie rozwoju i wychowania dziecka poprzez przekazanie mu wartości, norm oraz zasad postępowania, wpływając jednocześnie na kształtowanie postawy odpowiedzialności i dojrzałości życiowej.

Dzieci przebywające w pieczy zastępczej posiadają większą potrzebę stabilności, bezpieczeństwa i spójności emocjonalnej, muszą także odczuwać zainteresowanie oraz uwagę ze strony opiekunów. W procesie wychowawczym

38 S. Kawula, Rodzina jako grupa i instytucja opiekuńczo-wychowawcza, [w:] Pedagogika rodziny, red. S. Kawula, J. Brągiel, A. W. Janke, Toruń 1999, s. 55-56

39 Z. Węgierski, Opieka nad dzieckiem osieroconym: teoria i praktyka, Toruń 2006, s. 53.

40 A. Kelm, Węzłowe problemy pedagogiki opiekuńczej, Warszawa 2000, s. 57. 
ważna jest również konsekwencja w działaniu i postępowaniu rodziców zastępczych, motywowanie oraz stymulowanie dziecka do nauki, rozwijania zainteresowań, aktywnego spędzania czasu wolnego, a także angażowanie stosownie do wieku i możliwości dziecka w codzienne życie rodziny. Należy pamiętać, że podejmowane działania wychowawcze powinny przede wszystkim wzmocnić u dziecka poczucie własnej wartości, a także bezpieczeństwa i przynależności do rodziny.

\section{Bibliografia}

Andrzejewski M., Rodziny zastępcze - problematyka prawna, Toruń 2006.

Badora S., Czeredrecka B., Marzec D., Rodzina i formy jej wspomagania, Kraków 2001.

Czeredrecka B., Potrzeby psychiczne sierot społecznych, Warszawa 1988.

Główny Urząd Statystyczny, Opieka nad dzieckiem pozbawionym opieki rodzicielskiej (Notatka informacyjna), Warszawa 2014.

Jamrożek M., Matyjas B., Rodzina zastępcza, [w:] Encyklopedia pedagogiczna XXI wieku, t. 5, red. E. Różycka, Warszawa 2006.

Joachimowska M., Rodzicielstwo zastępcze. Idea - problemy - analizy - kompetencje, Bydgoszcz 2008.

Jundziłł I., Opieka nad rodzina w miejscu zamieszkania, Warszawa 1983.

Kawula S., Rodzina jako grupa i instytucja opiekuńczo-wychowawcza, [w:] Pedagogika rodzi$n y$, red. S. Kawula, J. Brągiel, A. W. Janke, Toruń 1999.

Kelm A., Węzłowe problemy pedagogiki opiekuńczej, Warszawa 2000.

Kępski Cz., Rodziny zastępcze w województwie lubelskim, „Problemy Opiekuńczo-Wychowawcze" (1985) $\mathrm{nr} 2$.

Kozak S., Sieroctwo społeczne, Warszawa 1986.

Kusio U., Rodzina zastępcza jako środowisko wychowawcze. Studium socjologiczne na przykładzie Lublina, Lublin 1998.

Lalak D., Pilch T., Elementarne pojęcia pedagogiki społecznej i pracy socjalnej, Warszawa 1999. Łopatkowa M., Samotność dziecka, Warszawa 1989.

Łuczyński A., Dzieci w rodzinach zastępczych i dysfunkcjonalnych, Lublin 2008.

Maciaszkowa J., Z teorii i praktyki pedagogiki opiekuńczej, Warszawa 1991.

Matejek J., Działalność ośrodków adopcyjno-opiekuńczych w procesie przygotowania $i$ wspierania rodzin zastępczych, Kraków 2008.

Matejek J., Banach M., Realizacja funkcji opiekuńczo-wychowawczych w rodzinach zastępczych, [w:] Dilema sociálnej pedagogiky: výchova alebo prostredie?, Vedecký zborník, edit. M. Pisoňová, D. Smetanová, M. Kuruc, Bratislava 2013.

Obuchowska I., Dziecko zagubione w sieroctwie, „Problemy Opiekuńczo-Wychowawcze” (1998) nr 5, s. 3-8. 
Olearczyk T. E., Sieroctwo i osamotnienie. Pedagogiczne problemy kryzysu współczesnej rodziny, Kraków 2008.

Ustawa z dnia 9 czerwca 2011 roku o wspieraniu rodziny i systemie pieczy zastępczej (Dz. U. z 2015, poz. 332).

Pawłowska R., Rola rodziny zastępczej w readaptacji dziecka osieroconego, „Problemy Opiekuńczo-Wychowawcze" (1987) nr 9.

Pawłowska R., Jundziłł I., Pedagogika człowieka samotnego, Gdańsk 2000.

Ruszkowska M., Diagnoza rodzin zastępczych w obliczu dylematów wspótczesności, Warszawa 2013.

Różańska E., Tynelski A., Rodzina zastępcza jako forma opieki nad dzieckiem, Kielce 1981.

Tynelski A., Rodzina zastępcza jako środowisko opiekuńczo-wychowawcze, „Problemy Opiekuńczo-Wychowawcze" (1976) nr 3.

Sakowicz T., Dysfunkcjonalność rodziny a resocjalizacja, Kraków 2006.

Sendyk M., Społeczne przystosowanie dzieci z poczuciem sieroctwa duchowego, Kraków 2001. Szymborska A., Sieroctwo społeczne, Warszawa 1969.

Wagner I., Sieroctwo społeczne - przyczyny, następstwa, formy kompensacji: studium teoretyczno-badawcze, Częstochowa 1997.

Węgierski Z., Opieka nad dzieckiem osieroconym: teoria i praktyka, Toruń 2006.

Winogrodzka L., Rodziny zastępcze i ich dzieci, Lublin 2007.

Wosik-Kawala D., Rodzinne i instytucjonalne środowiska opiekuńczo- wychowawcze, Lublin 2012. 
A. Uniwersytet Papieski T.5. Jana Pawła II 